\title{
Technical note: Evaluation of endogenous control gene expression in bovine neutrophils by reverse-transcription quantitative PCR using microfluidics gene expression arrays
}

\author{
M. A. Crookenden, ${ }^{*} \dagger^{1}$ C. G. Walker, ${ }^{* 2}$ B. Kuhn-Sherlock, $\ddagger$ A. Murray, $\dagger$ V. S. R. Dukkipati, $\dagger$ A. Heiser,,$\S$ \\ and J. R. Rocheł \\ *DairyNZ, c/o University of Auckland, 3A Symonds Street, Auckland 1010, New Zealand \\ †Institute of Vet, Animal and Biomedical Sciences, Massey University, Palmerston North 4442, New Zealand \\ ‡DairyNZ, Cnr Ruakura and Morrinsville Roads (SH26), Newstead, Hamilton 3284, New Zealand \\ $\S A g R e s e a r c h$, Hopkirk Research Institute, Palmerston North 4442, New Zealand
}

\section{ABSTRACT}

Reverse-transcription quantitative-PCR (RT-qPCR) is commonly used for assessing the cellular response to changes in physiologic and pathologic conditions. The selection of stable endogenous control genes is an important step of any RT-qPCR study, as expression can vary depending on the experimental environment. Our objective was to identify endogenous control genes in circulating neutrophils isolated from cows during the peripartum period. To do this, we used microfluidics gene expression arrays (Fluidigm, San Francisco, CA) for RT-qPCR analysis. Selection of the endogenous control genes was based on previous research investigating gene expression in neutrophils. The selected genes included $A C T B, B 2 M, G 6 P D, G A P D H, G C H 1$, GOLGA5, OSBPL2, PGK1, RPL13A, RPL19, RPS9, SDHA, SMUG1, SNRPA, TBP, UXT, and YWHAZ. Four genes (GAPDH, GOLGA5, PGK1, and UXT) did not provide satisfactory quantification results using the selected method and were therefore excluded from the analyses. The suitability of the remaining 13 genes for use as endogenous control genes was assessed using geNorm and Normfinder. The gene pair with the greatest stability using geNorm was $R P L 13 A$ and RPL19, whereas Normfinder ranked RPL19 and $Y W H A Z$ as the most stable pair. The 2 genes deemed most suitable for the experimental design were RPL19 and $Y W H A Z$, which were selected for subsequent gene expression analysis. This study highlights that genes used as endogenous controls for relative quantification

\footnotetext{
Received December 14, 2016.

Accepted April 10, 2017.

${ }^{1}$ Corresponding author: mallory.crookenden@dairynz.co.nz

${ }^{2}$ Current address: Growing Up in New Zealand, University of Auckland Tamaki Campus, Auckland 1072, New Zealand.
}

should be assessed on an experimental basis, even if the genes have been used in previous research.

Key words: polymorphonuclear leukocyte, internal control gene, reference genes

\section{Technical Note}

The immune system is dysregulated during the periparturient period in the transition dairy cow (Mallard et al., 1998; Heiser et al., 2015; Lange et al., 2016). Consequently, there is a high incidence of infectious disease during this time (Drackley et al., 2005; LeBlanc, 2010). Neutrophils are of particular interest due to their important role in defending against infectious disease (Cai et al., 1994). Neutrophil function is altered during the peripartum period in dairy cows (Detilleux et al., 1995); however, there are limited studies characterizing the extent of this alteration at the level of gene expression (GE). Furthermore, the selection of endogenous control genes for quantitative GE analysis requires further investigation.

Reverse-transcription quantitative PCR (RTqPCR) is a technique commonly used to analyze the expression of genes in a biological experiment (Bustin, 2002). Quantification of genes can inform changes in protein expression and enable changes in cell function to be inferred. Quantification is normally achieved by comparing abundance of target genes relative to the expression of known endogenous control genes, also known as housekeeping or reference genes (Vandesompele et al., 2002). The criteria for endogenous control genes include stable expression in the cell or tissue type under investigation and that they do not differ between treatment groups. The selection of stably expressed genes for target gene normalization is essential for accurate GE results (García-Vallejo et al., 2004; Janovick-Guretzky et al., 2007). Endogenous control GE can vary depending on cell or tissue type, as well 
as experimental conditions. Therefore, to accurately validate RT-qPCR experiments it is important to explore several possible endogenous control genes before relative quantification analysis.

One of the platforms available for RT-qPCR analysis is the BioMark HD (Fluidigm, San Francisco, CA), which utilizes microfluidics technology. In contrast to standard RT-qPCR using 384-well plates, the integrated fluidic circuits (IFC) used in the current study (96.96 Dynamic Array IFC; Fluidigm) generate 24 times the number of data points. Furthermore, the 96.96 IFCs allow quantification of 96 genes and 96 samples per chip using less reagents and starting material than standard RT-qPCR reactions of 10-20 $\mu \mathrm{L}$. For example, a 96.96 IFC requires $360 \mu \mathrm{L}$ of PCR master mix to generate 9,216 GE results, compared with $1.92 \mathrm{~mL}$ to generate 384 data points in a standard 384-well plate (using $10 \mu \mathrm{L}$ reaction volumes). The microfluidics technology provides intermediary throughput compared with GE throughput using standard RT-qPCR or microarray technology. Fluidigm IFC arrays have been used successfully for large-scale GE analysis (Guo et al., 2010; Viturro et al., 2014; Crookenden et al., 2016). The RTqPCR data from Fluidigm IFC arrays have been validated by comparison with those from an ABI 7900 HT platform using TaqMan assay technology (Devonshire et al., 2011). Here, we describe the use of microfluidics technology in combination with a different probe-based assay (Roche Diagnostics, Basel, Switzerland) using RT-qPCR for the selection of endogenous control genes that are suitable for GE analysis of circulating bovine neutrophils isolated during the transition period.

The Ruakura Animal Ethics Committee (Hamilton, New Zealand) approved all animal manipulations in accordance with the New Zealand Animal Welfare Act (Ministry of Primary Industries, 1999). The experiment was undertaken at Scott Farm, Hamilton, New Zealand $\left(37^{\circ} 46^{\prime} \mathrm{S} 175^{\circ} 18^{\prime} \mathrm{E}\right)$ between July and October 2013.

A subset of cows of mixed age and breed (HolsteinFriesian, Jersey, Holstein-Friesian $\times$ Jersey) were selected from a parent transition cow experiment; described in detail by Roche et al. (2015). Cows were one of 2 BCS categories (4.0 or 5.0; based on a 10-point scale, equivalent to approximately 2.75 and 3.25 , respectively, on a 5-point scale; Roche et al., 2004) and one of 2 levels of energy intake preceding calving (75 or $125 \%$ of estimated requirements). Blood was sampled by coccygeal venipuncture at 5 time points over the transition period: 1 wk before estimated calving date $(-1 \mathrm{wk} ; \mathrm{n}=46)$, day of calving $(\mathrm{d} 0 ; \mathrm{n}=46)$, and $\mathrm{d} 7$ $(1 \mathrm{wk} ; \mathrm{n}=46), 14(2 \mathrm{wk} ; \mathrm{n}=45)$, and 28 (4 wk; $\mathrm{n}=$ 43) postcalving.

Blood for neutrophil isolation (total of $\sim 50 \mathrm{~mL} / \mathrm{cow}$ at each time point) was collected in 6 evacuated blood tubes (Vacutainer, BD Bioscience, Plymouth, UK) containing acid citrate dextrose (solution A; $22.0 \mathrm{~g} / \mathrm{L}$ of trisodium citrate, $8.0 \mathrm{~g} / \mathrm{L}$ of citric acid, and 24.5 $\mathrm{g} / \mathrm{L}$ of dextrose). Blood tubes were inverted 8 times and placed immediately on ice awaiting neutrophil isolation by differential centrifugation based on protocols described elsewhere (Osorio et al., 2013; Moyes et al., 2014; Crookenden et al., 2016). Total RNA was extracted from neutrophils using TRIzol reagent (Life Technologies, Auckland, New Zealand) as per the manufacturers' instructions (https://tools.thermofisher.com/content/sfs/manuals/trizol_reagent.pdf). All RNA samples were DNase treated using the Ambion DNA-free kit (Life Technologies). The quantity and purity of RNA was determined by spectrophotometry using a Nanodrop ND-1000 (Nanodrop Technologies, Wilmington, DE), which measures the optical density (OD) at the absorption ratio $\mathrm{OD}_{260 \mathrm{~nm}}: \mathrm{OD}_{280 \mathrm{~nm}}$. Quantity of total RNA per sample ranged from 2.7 to 112.1 $\mu \mathrm{g}$ with an average $( \pm \mathrm{SD})$ of $29.6 \pm 19.1 \mu \mathrm{g}$. The RNA was considered of sufficient purity for cDNA synthesis if the $\mathrm{OD}_{260 \mathrm{~nm}}: \mathrm{OD}_{280 \mathrm{~nm}}$ was $>1.80$. The RNA integrity was confirmed using an Agilent 2100 Bioanalyzer and RNA 6000 Nano LabChip kit (Agilent Technologies, Santa Clara, CA). Samples had an average RNA integrity number $( \pm \mathrm{SD})$ of $8.0 \pm 0.77$. Samples were stored at $-80^{\circ} \mathrm{C}$ until cDNA synthesis.

Total RNA $(2 \mu \mathrm{g})$ from each sample was reverse transcribed using a Superscript III Supermix kit (Life Technologies) with random pentadecamer primers (Integrated DNA Technologies, Singapore) at a final concentration of $27 \mu M$. Reverse-transcription negative controls were also generated by excluding the enzyme, and cDNA samples were stored at $-20^{\circ} \mathrm{C}$.

A diagram of the RT-qPCR workflow is displayed in Figure 1. Seventeen endogenous control genes were selected based on current literature (Table 1). The primer design for these genes for use in RT-qPCR was undertaken using publicly available bovine gene sequences from the National Center for Biotechnology Information gene database (http://www.ncbi.nlm.nih.gov). Assays were designed to span an exon-exon junction where possible, using Roche Universal Probe Library (UPL) design software (Table 2). Primer sequences were verified by Basic Local Alignment Search Tool (BLAST) and PrimerBLAST analysis (National Center for Biotechnology Information) to ensure specificity.

Assays were tested using 2 standard curves on a LightCycler 480 instrument (Roche). To do this, cDNA from 2 samples (from 2 divergent treatment groups) were serially diluted to make a 6 -point 10 -fold standard curve starting at $1 \times$ dilution to $1 \times 10^{-6}$ dilution. Each $10 \mu \mathrm{L}$ of RT-qPCR reaction contained custom-designed forward and reverse primers (200 n $M$, Integrated DNA 

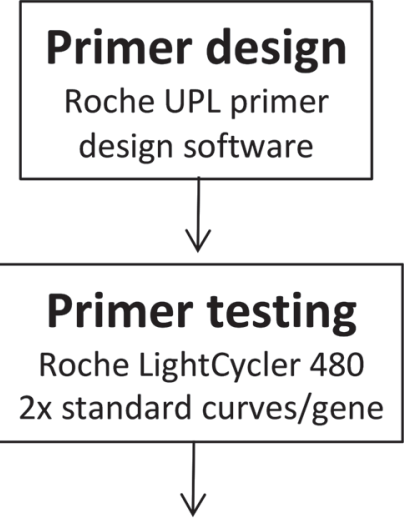

\section{Microfluidics RT-qPCR}

96.96 IFC (Fluidigm)

17 endo con +79 target genes

$1 x$ standard curve/gene

BioMark HD system (Fluidigm)

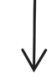

\section{Gene expression results}

Fluidigm Real-Time PCR Analysis software

\section{Endo con gene selection using GeNorm and Normfinder}

Figure 1. Diagram depicting the workflow employed for reversetranscription quantitative PCR (RT-qPCR) analysis including primer design through to gene expression results. UPL $=$ universal probe library; IFC = integrated fluidic circuit; endo con = endogenous control gene. LightCycler, Roche, Basel, Switzerland; Fluidigm, San Francisco, California. geNorm (Vandesompele et al., 2002); NormFnder (Andersen et al., 2004).

Technologies), UPL unique probe (50 n $M$, Roche), LightCycler 480 Probes Master $(2 \times$ concentrated), and RNase/DNase-free distilled water. Standard cycling conditions were used $\left[95^{\circ} \mathrm{C}\right.$ for $10 \mathrm{~min},\left(95^{\circ} \mathrm{C}\right.$ for $10 \mathrm{~s}$, $60^{\circ} \mathrm{C}$ for $\left.30 \mathrm{~s}\right) \times 50$ cycles, $40^{\circ} \mathrm{C}$ for $\left.40 \mathrm{~s}\right]$. Positive and negative samples were verified with gel electrophoresis to ensure a single product free of genomic DNA contamination and to verify the amplicon size.

Quantification of the endogenous control genes by RT-qPCR was achieved using the BioMark HD realtime PCR system (Ramaciotti Centre, NSW, Australia). Three microfluidics 96.96 Dynamic Array IFC chips (Fluidigm, San Francisco, CA) combined with Roche UPL chemistry were used to generate expression results for 17 endogenous control genes for all neutrophil samples $(\mathrm{n}=226)$. Controls containing no template as well as reverse-transcription negative controls were included on each IFC. All samples were run individually, as per manufacturers' recommendations. Four samples were run in duplicate across each chip to calculate well-

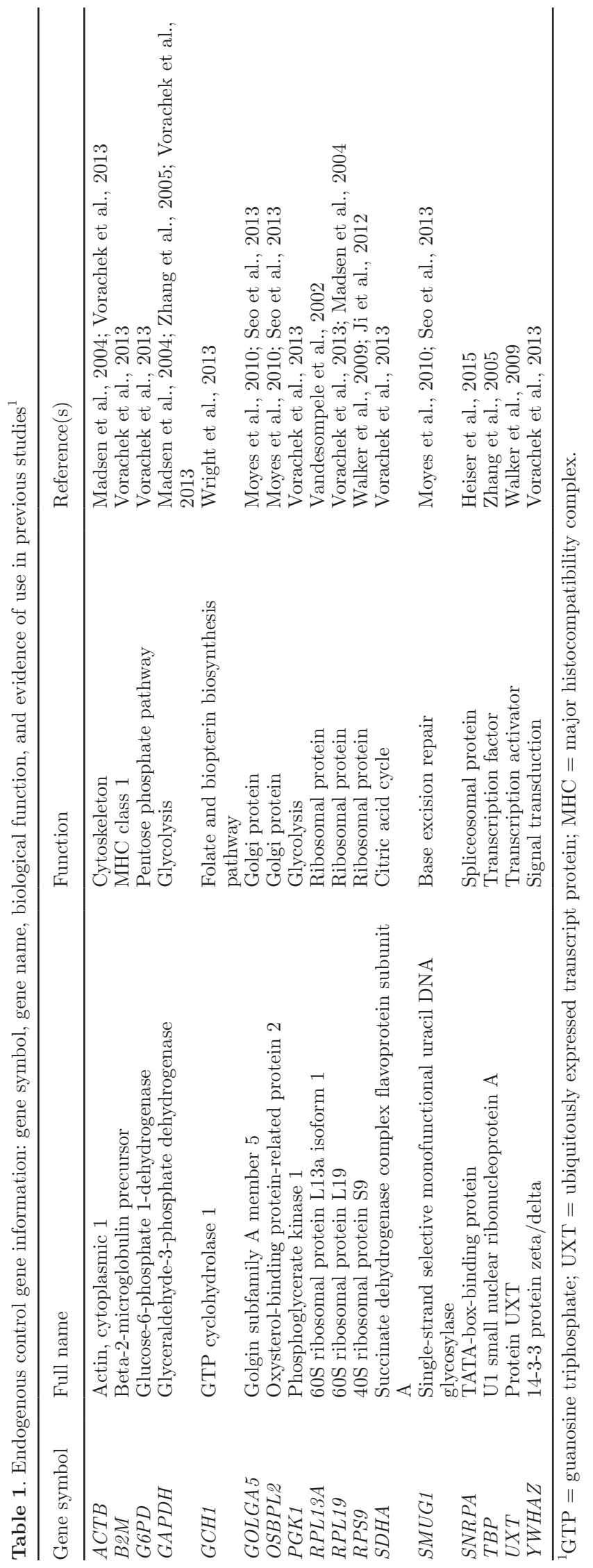

Journal of Dairy Science Vol. 100 No. 8, 2017 


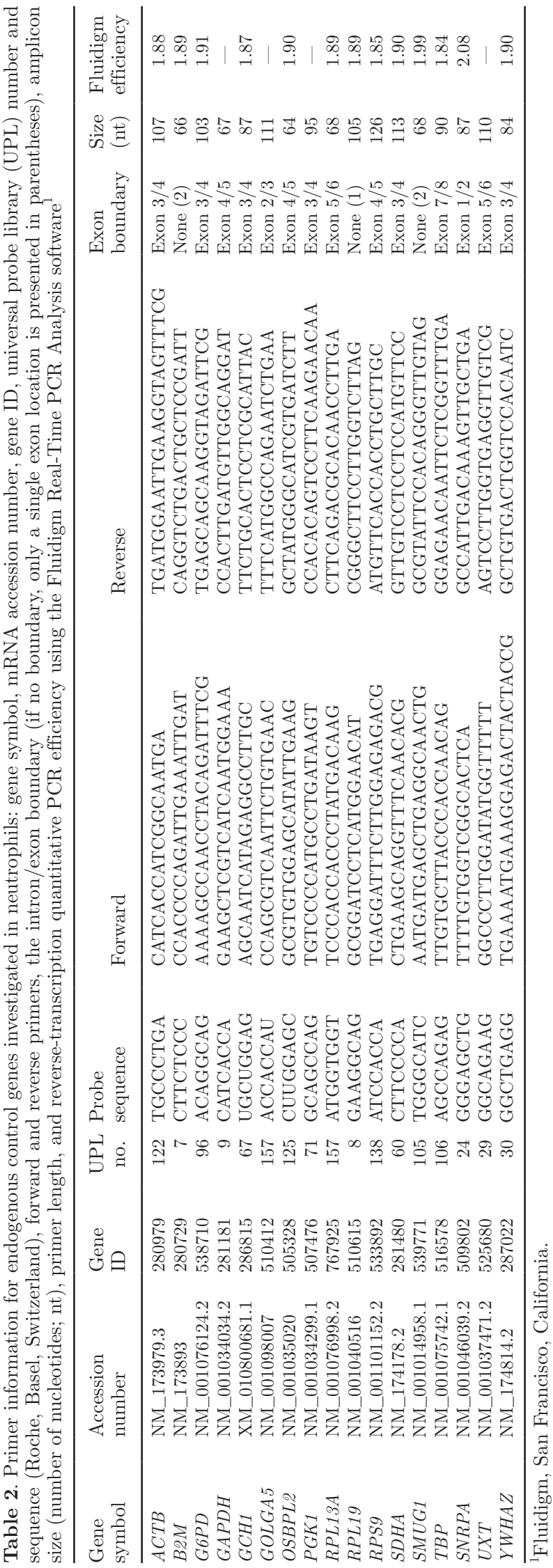

to-well and chip-to-chip coefficient of variation (data not presented). A pre-amplification of all sample cDNA (1.25 $\mu \mathrm{L}$ of $1: 4$ diluted cDNA per chip) was undertaken (as per recommended instructions due to the nanoscale volumes used by the IFC) to create specific target amplified reactions. This was achieved by multiplexing forward and reverse primers $(200 \mathrm{n} M)$ of the 96 assays with $5 \times$ concentration PreAmp Master Mix (Fluidigm) and the following cycling protocol: $95^{\circ} \mathrm{C}$ for 10 min, followed by 14 cycles $\times\left(95^{\circ} \mathrm{C}\right.$ for $15 \mathrm{~s}$ and $60^{\circ} \mathrm{C}$ for $4 \mathrm{~min})$. Assay mixtures, including forward and reverse primers $(800 \mathrm{n} M)$, Roche UPL probes $(100 \mathrm{n} M)$, and 2 $\times$ concentration assay loading reagent (Fluidigm), were combined with $2 \times$ concentration Roche LightCycler 480 Probes Master (Roche) and $20 \times$ GE sample loading reagent (Fluidigm) on a 96.96 IFC (Fluidigm) for use in the BioMark HD instrument. The GE cycling protocol GE $96 \times 96$ UPL v1.pcl (BioMark HD Data Collection software v3.0.2), $70^{\circ} \mathrm{C}$ for $30 \mathrm{~min}, 25^{\circ} \mathrm{C}$ for $10 \mathrm{~min}, 95^{\circ} \mathrm{C}$ for $1 \mathrm{~min}$ followed by 35 cycles of $96^{\circ} \mathrm{C}$ for $5 \mathrm{~s}$ and $60^{\circ} \mathrm{C}$ for $20 \mathrm{~s}$, was used to generate crossing point values (Figure 2).

A 5-point standard curve was included (3-fold serial dilutions from $3.33 \times 10^{-1}$ to a final dilution of $4.12 \times$ $10^{-3}$ ) from one pre-amplified sample to calculate the RT-qPCR efficiency of all gene assays. The assay efficiency (Table 2) was calculated using the slope of the standard curve (Yuan et al., 2006). Endogenous control gene stability was tested across all samples using geNorm (Vandesompele et al., 2002) and NormFinder (Andersen et al., 2004) software (Figures 3 and 4, respectively).

This study is the first to investigate potential endogenous control genes in bovine neutrophils using microfluidics technology. The genes YWHAZ and RPL19 were selected as the most suitable for GE analysis using relative quantification, despite having the best stability in only one of the endogenous control gene analyses. Although RPL19 expression was categorized as the most stable in both software packages, the expression of $Y W H A Z$ was ranked the most stable in combination with RPL19 using the NormFinder software (stability of 0.072 ), but not the geNorm software (Table 3 ). The final selection was based on the following rationale: (1) more weighting was placed on the NormFinder analysis because this software considers GE variation attributed to treatment group (Andersen et al., 2004; De Spiegelaere et al., 2015), and (2) the use of 2 ribosomal genes as endogenous control genes was avoided to avert potential bias (Vandesompele et al., 2002). Three treatment groups were included in the GE data in the current study and the inter- and intravariation among groups were considered using NormFinder. In comparison, the geNorm software uses pairwise stability to find 


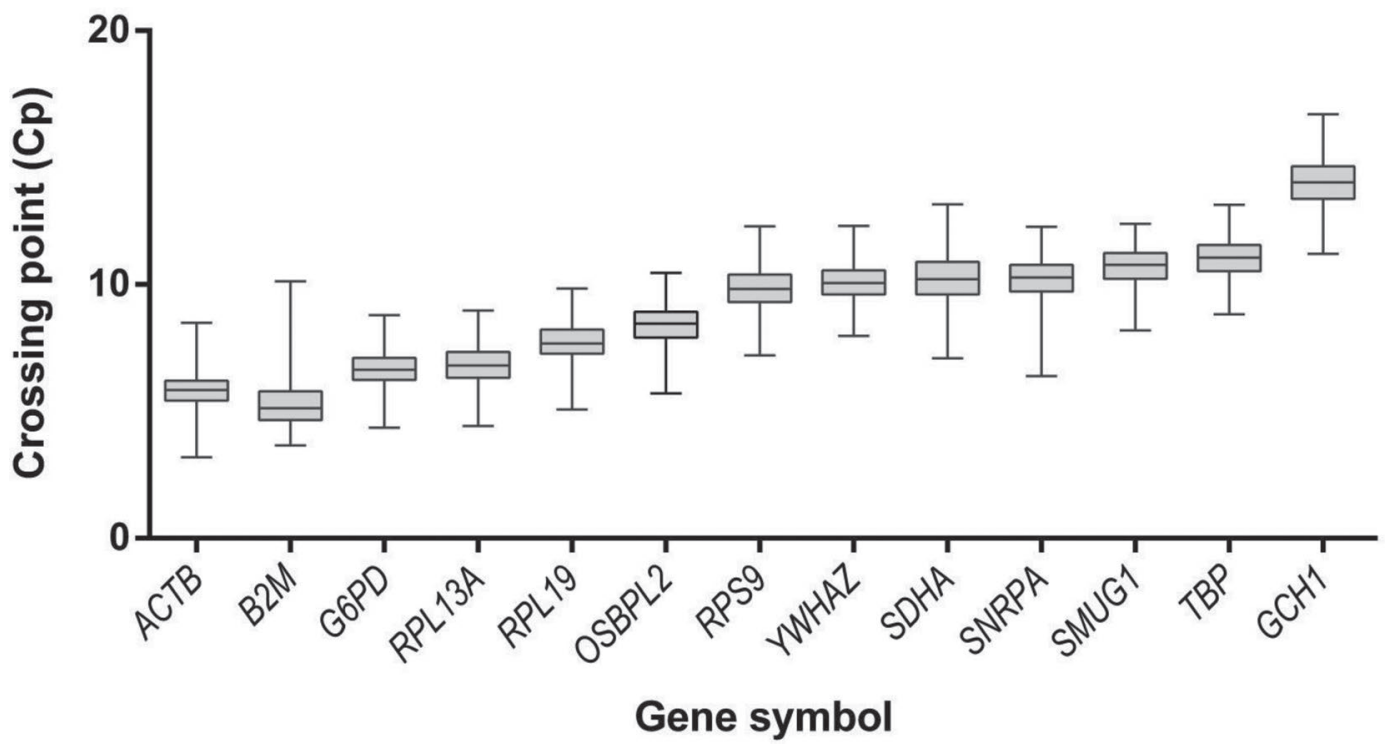

Figure 2. Expression graph of candidate endogenous control genes in bovine neutrophil samples using Microfluidics 96.96 gene expression arrays (Fluidigm, San Francisco, CA). Values are presented as the crossing point (Cp)/cycle threshold (Ct) and are inversely proportional to the amount of template. Expression levels are demonstrated as the 25th and 75th quartiles (horizontal lines), median (central horizontal line), and whiskers. Whiskers represent the minimum to maximum Cp value. Genes are ordered from the most abundant (lower Ct, on the left) to least abundantly expressed (higher $\mathrm{Ct}$, on the right).

2 optimal genes that have an equal expression ratio in all samples. This provides information on how many endogenous control genes should be used to improve stability (Figure 5). However, the most stable genes using the geNorm software often have similar expression patterns (e.g., ribosomal genes; rRNA). Vandesompele et al. (2002) advise caution when selecting rRNA molecules as endogenous control genes because rRNA

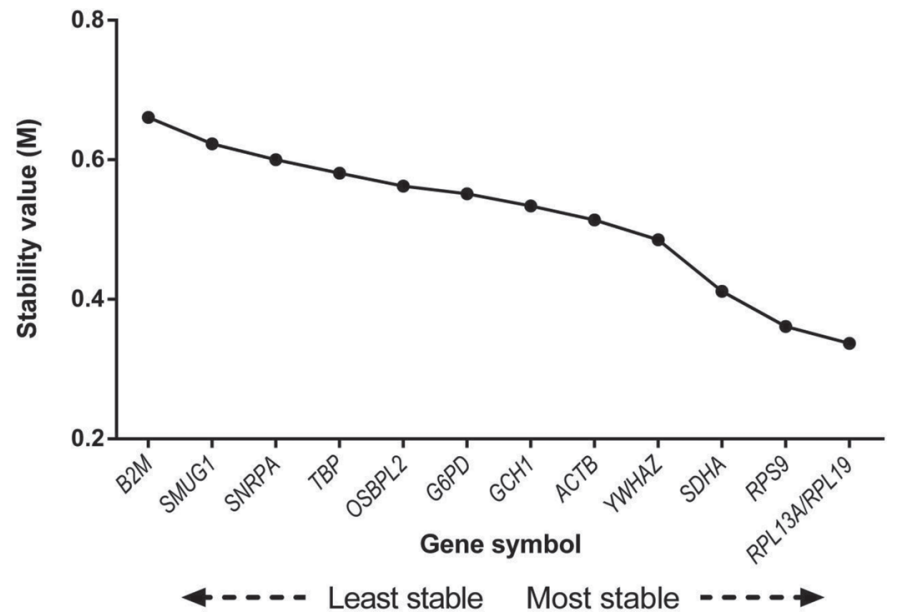

Figure 3. Expression stability of endogenous control genes analyzed by geNorm (Vandesompele et al., 2002). Average expression stability values $(\mathrm{M})$ following stepwise exclusion of the least stable reference genes across all treatment groups. A lower $M$ value indicates more stable gene expression. expression may not be a good representation of the total mRNA pool. The final selection of endogenous control genes should consider experimental design and gene regulation to avoid selecting genes that are coregulated. The use of rRNA genes as the chosen endogenous control genes was, therefore, disregarded, despite the rRNA pair of $R P L 13 A$ and RPL19 having the best stability in geNorm.

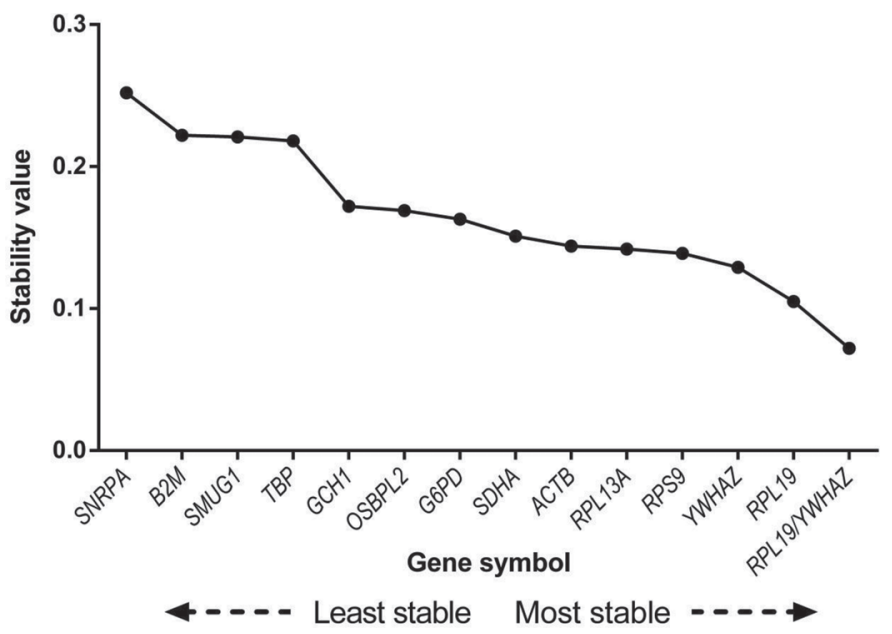

Figure 4. Expression stability of the candidate reference genes analyzed by NormFinder (Andersen et al., 2004) including the combination of the 2 most stable genes (RPL19 and YWHAZ). 


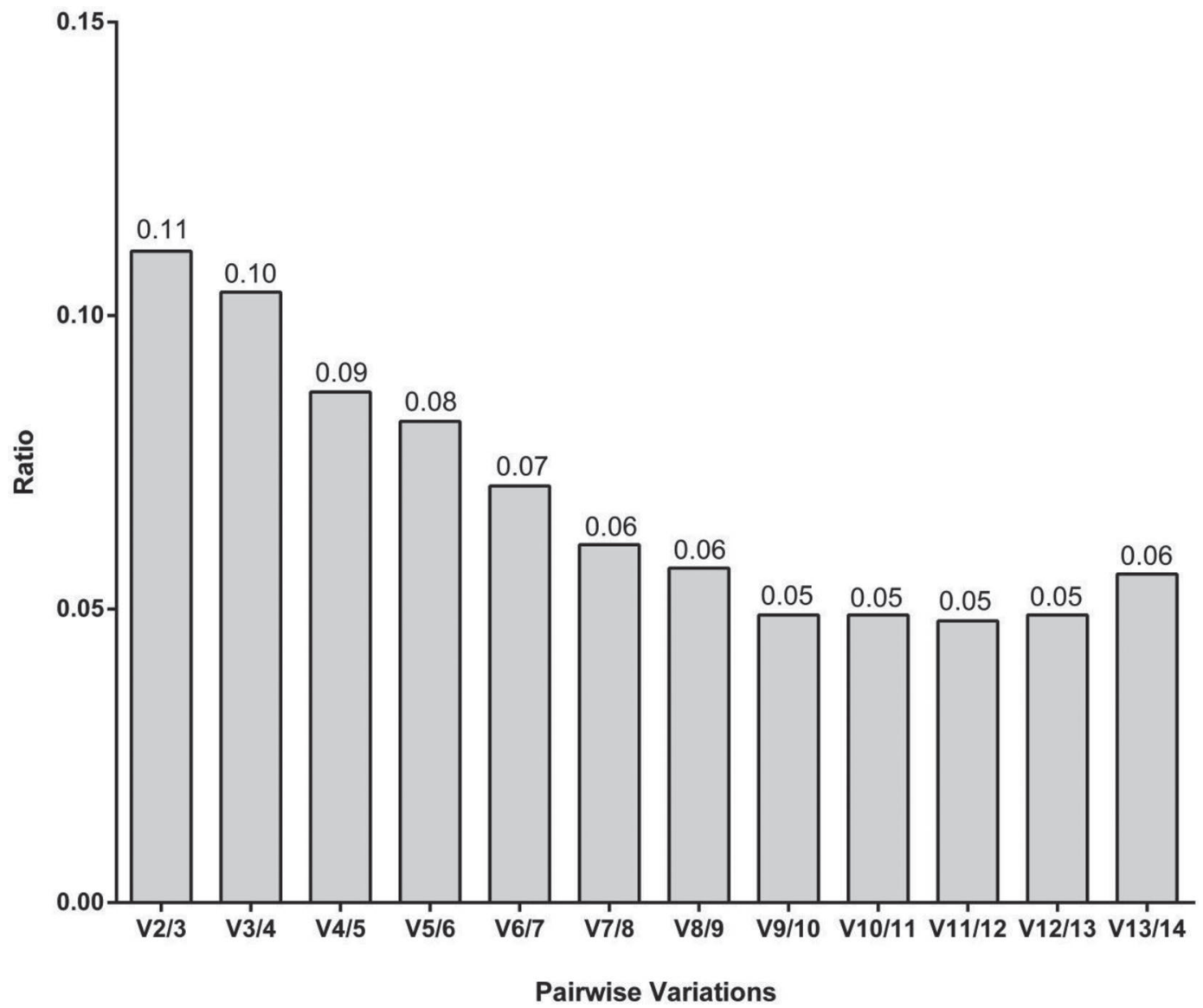

Figure 5. Pairwise variation $(\mathrm{Vn} / \mathrm{Vn}+1)$ between the normalization factors $\mathrm{NF}_{\mathrm{n}}$ and $\mathrm{NF}_{\mathrm{n}+1}$ to determine the optimal number of reference genes for normalization using geNorm (Vandesompele et al., 2002). A recommended ratio is $<0.15$.

It is likely that some assays were inhibited during the RT-qPCR protocol using microfluidic IFC arrays and would require further optimization for use with a microfluidics platform. The expression data of 4 genes (GAPDH, GOLGA5, PGK1, and UXT) were below the fluorescence threshold for quantification analysis and were, therefore, excluded from endogenous control gene data analysis. These genes were expected to be expressed by circulating neutrophils based on primer optimization and previous studies (Holzer et al., 2005;

Table 3. Ranking of the candidate genes according to their stability using NormFinder (Andersen et al., 2004) and geNorm (Vandesompele et al., 2002) analyses

\begin{tabular}{llcllc}
\hline \multicolumn{3}{c}{ NormFinder } & & \multicolumn{2}{c}{ geNorm } \\
Rank & Gene symbol & Stability & & Gene symbol & Stability \\
\hline 1 & RPL19/YWHAZ & 0.072 & & RPL13A/RPL19 & 0.337 \\
2 & RPS9 & 0.139 & & RPS9 & 0.361 \\
3 & RPL13A & 0.142 & & SDHA & 0.412 \\
4 & ACTB & 0.144 & & YWHAZ & 0.485 \\
5 & SDHA & 0.151 & & ACTB & 0.514 \\
6 & G6PD & 0.163 & & GCH1 & 0.534 \\
7 & OSBPL2 & 0.169 & & G6PD & 0.551 \\
8 & TBH1 & 0.172 & & OSBPL2 & 0.562 \\
9 & SMUG1 & 0.218 & & TBP & 0.581 \\
10 & B2M & 0.221 & & SNRPA & 0.600 \\
11 & SNRPA & 0.222 & & SMUG1 & 0.623 \\
12 & & 0.252 & & B2M & 0.661 \\
\hline
\end{tabular}


Seo et al., 2013; Vorachek et al., 2013; Bai et al., 2014). A possible reason for inhibition is that the starting cDNA was too concentrated. In support of this, expression curves that passed the fluorescence threshold were evident for genes GOLGA5, PGK1, and UXT at lower concentrations of the standard curve. The RT-qPCR reactions can fail when concentrations of primers are too high, or in the presence of amplification inhibitors (Cone et al., 1992; Gallup and Ackermann, 2006). An advantage of the microfluidics chip is that small amounts of cDNA are required to generate expression data for 96 genes. This is because the structural design of the chip means that all 96 assays are added to a reaction mix containing the individual sample cDNA (White et al., 2011). However, starting concentrations are amplified when the reagents are injected into the microfluidic circuit. This may cause inhibition in some cases due to the starting concentrations being too high. This inhibition is normally overcome by using different dilutions of cDNA, which is calculated based on cycle thresholds generated during primer optimization. A drawback of the IFC array is that it does not support running samples at different concentrations as all the GE data are generated in one reaction vessel of $6.7 \mathrm{~nL}$ volume (White et al., 2011). Furthermore, one aspect of endogenous control GE that is often not considered is that control genes should have similar expression levels as target genes. The selection of genes for use with microfluidics technology should consider the relative expression to ensure the dynamic range is not outside the limits of the technology.

The 17 genes selected for investigation have been used as endogenous control genes in previous RT-qPCR studies (Table 1), highlighting the importance of validating reference genes appropriate for the experimental design. Furthermore, Figure 6 demonstrates the relative expression $(\triangle \mathrm{Ct})$ of 1 target gene $(S E L L)$ over the transition period normalized to different endogenous control gene pairs. All normalizations demonstrated significant $(P<0.05)$ changes over time with similar expression curves, with the exception of the normalization with B2M and SMUG1. Tukey comparisons between weeks indicated that significance changed depending on the genes used for normalization, highlighting the importance of a descriptive selection process. The stability results presented here are consistent with rankings in previous studies; however, several of these commonly used endogenous control genes were not considered appropriate for GE analysis of bovine neutrophils. De Ketelaere et al. (2006) identified $Y W H A Z, S D H A$, and $18 S$ rRNA as the most stable genes in bovine neutrophils, which is consistent with our results. In comparison, Bai et al. (2014) identified UXT and RPS9 to be among the most stable reference genes; however, their study used neutrophils isolated from yak (Bos grunniens) milk. The most extensive endogenous control gene study in circulating neutrophils from ruminant animals was conducted on cells isolated from sheep

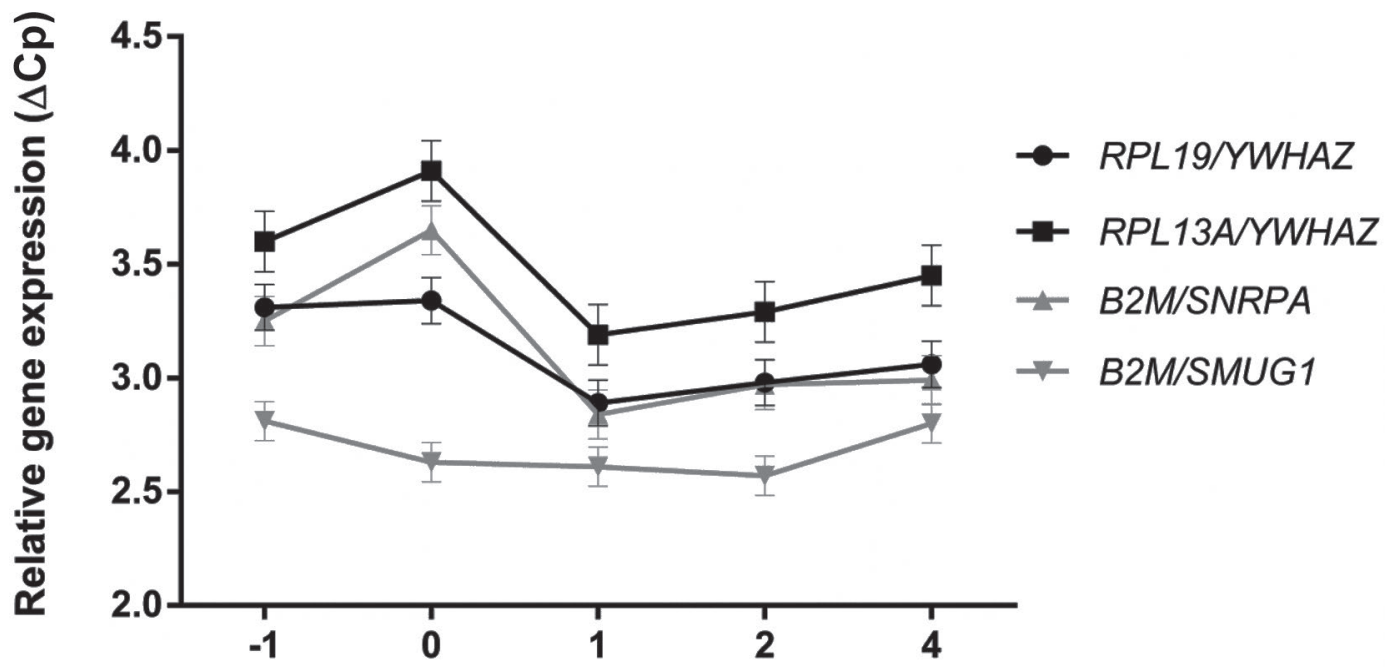

Time relative to calving $(0)$ in weeks

Figure 6. Relative gene expression $(\triangle \mathrm{Cp})$ of L-selectin $(S E L L)$ during the transition period using different pairs of genes for normalization. Pairs were chosen based on geNorm (Vandesompele et al., 2002) and NormFinder (Andersen et al., 2004) results (Table 3) by selecting the most stable genes (black lines) and the least stable genes (gray lines). A repeated measures ANOVA (SAS 9.3, SAS Institute Inc., Cary, NC) was used to determine the effect of time (week) on gene expression. All comparisons demonstrated significant $(P<0.05)$ changes in $S E L L$ gene expression over time. However, Tukey comparisons between time points differed between normalization calculations. 
(Ovis aries) under different disease states (Vorachek et al., 2013). In agreement with the results of our study, genes PGK1, ACTB, and B2M were considered unreliable endogenous control genes. However, Vorachek et al. (2013) concluded that 2 different sets of endogenous controls were suitable, depending on the disease state: $S D H A / G 6 P D$ in healthy sheep and GAPDH/YWHAZ in diseased sheep. Our study used healthy cattle (Bos taurus); the results suggest that species-specific differences must also be considered.

Furthermore, previous studies investigating endogenous control gene selection in neutrophils have not used microfluidics technology for RT-qPCR analysis (Zhang et al., 2005; De Ketelaere et al., 2006; Vorachek et al., 2013; Bai et al., 2014). Added variation is introduced with the preamplification required for RT-qPCR using IFC arrays, which is evident when comparing well-towell and plate-to-plate variation in samples that have undergone preamplification independently (Spurgeon et al., 2008). Future investigations will compare the results from Fluidigm microfluidics IFC arrays and the Roche LightCycler480 for which the assay chemistry was designed. In summary, multiple factors highlighted in the current study must be considered when selecting endogenous control genes: the technology employed, the cell (or tissue) type, and the species of origin.

In conclusion, microfluidics technology is a powerful tool for GE analysis. The cost per gene is less compared with conventional RT-qPCR methods due to the reduced volume of expensive reagents required. We have demonstrated that the use of Roche UPL chemistry is compatible with the Fluidigm GE arrays. Furthermore, we recommend using the geometric mean of the 2 commonly used endogenous control genes RPL19 and $Y W H A Z$ for GE analysis in bovine neutrophils. This study emphasizes that it is essential to validate endogenous control genes in a RT-qPCR experiment by comparing the stability of multiple genes.

\section{ACKNOWLEDGMENTS}

The authors acknowledge farm staff (Scott Farm, DairyNZ), in particular Jason Philips (farm manager). We also acknowledge DairyNZ technical staff, Stu Morgan, Kate Watkins, Hamish Hodgson, and Chris Roach, for technical support and assistance with animal handling and sample collection. Furthermore, we acknowledge the Ramaciotti Centre for Genomics, University of New South Wales, Sydney, Australia, for conducting the RT-qPCR workflow using the microfluidics dynamic arrays. This work was supported by funding from New Zealand dairy farmers, through DairyNZ Inc. (RD1403), Hamilton, New Zealand, and the Ministry of Business, Innovation and Employment (DRCX1201), Wellington, New Zealand.

\section{REFERENCES}

Andersen, C. L., J. L. Jensen, and T. F. Ørntoft. 2004. Normalization of real-time quantitative reverse transcription-PCR data: A model-based variance estimation approach to identify genes suited for normalization, applied to bladder and colon cancer data sets. Cancer Res. 64:5245-5250.

Bai, W. L., R. H. Yin, S. J. Zhao, W. Q. Jiang, R. L. Yin, Z. J. Ma, Z Y. Wang, Y. B. Zhu, G. B. Luo, R. J. Yang, and Z. H. Zhao. 2014 Technical note: Selection of suitable reference genes for studying gene expression in milk somatic cell of yak (Bos grunniens) during the lactation cycle. J. Dairy Sci. 97:902-910. https://doi. org/10.3168/jds.2012-6437.

Bustin, S. A. 2002. Quantification of mRNA using real-time reverse transcription PCR (RT-PCR): Trends and problems. J. Mol. Endocrinol. 29:23-39. https://doi.org/10.1677/jme.0.0290023.

Cai, T. Q., P. G. Weston, L. A. Lund, B. Brodie, D. J. McKenna, and W. C. Wagner. 1994. Association between neutrophil functions and periparturient disorders in cows. Am. J. Vet. Res. 55:934-943.

Cone, R. W., A. C. Hobson, and M. W. Huang. 1992. Coamplified positive control detects inhibition of polymerase chain reactions. J. Clin. Microbiol. 30:3185-3189.

Crookenden, M. A., A. Heiser, A. Murray, V. S. R. Dukkipati, J. K. Kay, J. J. Loor, S. Meier, M. D. Mitchell, K. M. Moyes, C. G. Walker, and J. R. Roche. 2016. Parturition in dairy cows temporarily alters the expression of genes in circulating neutrophils. J. Dairy Sci. 99:6470-6483. https://doi.org/10.3168/jds.2015-10877.

De Ketelaere, A., K. Goossens, L. Peelman, and C. Burvenich. 2006. Technical note: Validation of internal control genes for gene expression analysis in bovine polymorphonuclear leukocytes. J. Dairy Sci. 89:4066-4069. https://doi.org/10.3168/jds.S00220302(06)72450-X

De Spiegelaere, W., J. Dern-Wieloch, R. Weigel, V. Schumacher, H Schorle, D. Nettersheim, M. Bergmann, R. Brehm, S. Kliesch, L. Vandekerckhove, and C. Fink. 2015. Reference gene validation for RT-qPCR, a note on different available software packages. PLoS One 10:e0122515. https://doi.org/10.1371/journal.pone.0122515.

Detilleux, J. C., M. E. Kehrli, J. R. Stabel, A. E. Freeman, and D. H Kelley. 1995. Study of immunological dysfunction in periparturient Holstein cattle selected for high and average milk production. Vet. Immunol. Immunopathol. 44:251-267.

Devonshire, A. S., R. Elaswarapu, and C. A. Foy. 2011. Applicability of RNA standards for evaluating RT-qPCR assays and platforms. BMC Genomics 12:118. https://doi.org/10.1186/1471-2164-12118.

Drackley, J. K., H. M. Dann, G. N. Douglas, N. A. J. Guretzky, N. B. Litherland, J. P. Underwood, and J. J. Loor. 2005. Physiological and pathological adaptations in dairy cows that may increase susceptibility to periparturient diseases and disorders. Ital. J. Anim. Sci. 4:323-344.

Gallup, J. M., and M. R. Ackermann. 2006. Addressing fluorogenic real-time qPCR inhibition using the novel custom Excel file system "FocusField2-6GallupqPCRSet-upTool-001" to attain consistently high fidelity qPCR reactions. Biol. Proced. Online 8:87-152. https://doi.org/10.1251/bpo122.

García-Vallejo, J. J., B. Van Het Hof, J. Robben, J. A. E. Van Wijk, I. Van Die, D. H. Joziasse, and W. Van Dijk. 2004. Approach for defining endogenous reference genes in gene expression experiments. Anal. Biochem. 329:293-299. https://doi.org/10.1016/j. ab.2004.02.037.

Guo, G., M. Huss, G. Q. Tong, C. Wang, L. Li Sun, N. D. Clarke, and P. Robson. 2010. Resolution of cell fate decisions revealed by single-cell gene expression analysis from zygote to blastocyst. Dev. Cell 18:675-685. https://doi.org/10.1016/j.devcel.2010.02.012.

Heiser, A., A. Mccarthy, N. Wedlock, S. Meier, J. Kay, C. Walker, M. A. Crookenden, M. D. Mitchell, S. Morgan, K. Watkins, 
J. J. Loor, and J. R. Roche. 2015. Grazing dairy cows had decreased interferon- $\gamma$, tumor necrosis factor, and interleukin-17, and increased expression of interleukin-10 during the first week after calving. J. Dairy Sci. 98:937-946. https://doi.org/10.3168/ jds.2014-8494.

Holzer, K., F. Schübel, P. Konietzny, K. Wilhelm, W.-O. Bechstein, and D. Henrich. 2005. Interleukin 8 mRNA gene expression in peripheral and intra-abdominal neutrophils during human secondary peritonitis. Shock 23:501-506. https://doi.org/10.1097/01. shk.0000161389.69559.92.

Janovick-Guretzky, N. A., H. M. Dann, D. B. Carlson, M. R. Murphy, J. J. Loor, and J. K. Drackley. 2007. Housekeeping gene expression in bovine liver is affected by physiological state, feed intake, and dietary treatment. J. Dairy Sci. 90:2246-2252. https://doi. org/10.3168/jds.2006-640.

Ji, P., J. S. Osorio, J. K. Drackley, and J. J. Loor. 2012. Overfeeding a moderate energy diet prepartum does not impair bovine subcutaneous adipose tissue insulin signal transduction and induces marked changes in peripartal gene network expression. J. Dairy Sci. 95:4333-4351. https://doi.org/10.3168/jds.2011-5079.

Lange, J., A. Mccarthy, J. Kay, S. Meier, C. Walker, M. A. Crookenden, M. D. Mitchell, J. J. Loor, J. R. Roche, and A. Heiser. 2016. Prepartum feeding level and body condition score affect immunological performance in grazing dairy cows during the transition period performance in grazing dairy cows during the transition period. J. Dairy Sci. 99:2329-2338. https://doi.org/10.3168/ jds.2015-10135.

LeBlanc, S. 2010. Monitoring metabolic health of dairy cattle in the transition period. J. Reprod. Dev. 56(Suppl.):S29-S35.

Madsen, S. A., L.-C. Chang, M.-C. Hickey, G. J. M. Rosa, P. M. Coussens, and J. L. Burton. 2004. Microarray analysis of gene expression in blood neutrophils of parturient cows. Physiol. Genomics 16:212-221. https://doi.org/10.1152/physiolgenomics.00121.2003.

Mallard, B. A., J. C. Dekkers, M. J. Ireland, K. E. Leslie, S. Sharif, C. Lacey Vankampen, L. Wagter, and B. N. Wilkie. 1998. Alteration in immune responsiveness during the peripartum period and its ramification on dairy cow and calf health. J. Dairy Sci. 81:585595. https://doi.org/10.3168/jds.S0022-0302(98)75612-7.

Ministry of Primary Industries. 1999. New Zealand Animal Welfare Act. Part 6. Use of animals in research, testing, and teaching. Accessed Jan. 24, 2015. http://www.legislation.govt.nz/act/ public/1999/0142/latest/DLM49664.html.

Moyes, K. M., J. K. Drackley, D. E. Morin, S. L. Rodriguez-Zas, R. E. Everts, H. A. Lewin, and J. J. Loor. 2010. Mammary gene expression profiles during an intramammary challenge reveal potential mechanisms linking negative energy balance with impaired immune response. Physiol. Genomics 41:161-170. https://doi. org/10.1152/physiolgenomics.00197.2009.

Moyes, K. M., D. E. Graugnard, M. J. Khan, M. Mukesh, and J. J. Loor. 2014. Postpartal immunometabolic gene network expression and function in blood neutrophils are altered in response to prepartal energy intake and postpartal intramammary inflammatory challenge. J. Dairy Sci. 97:2165-2177. https://doi.org/10.3168/ jds.2013-7433.

Osorio, J. S., E. Trevisi, M. A. Ballou, G. Bertoni, J. K. Drackley, and J. J. Loor. 2013. Effect of the level of maternal energy intake pre- partum on immunometabolic markers, polymorphonuclear leukocyte function, and neutrophil gene network expression in neonatal Holstein heifer calves. J. Dairy Sci. 96:3573-3587.

Roche, J. R., P. G. Dillon, C. R. Stockdale, L. H. Baumgard, and M. J. VanBaale. 2004. Relationships among international body condition scoring systems. J. Dairy Sci. 87:3076-3079. https://doi. org/10.3168/jds.S0022-0302(04)73441-4.

Roche, J. R., S. Meier, A. Heiser, M. D. Mitchell, C. G. Walker, M. A. Crookenden, M. V. V. Riboni, J. J. Loor, and J. K. Kay. 2015. Effects of precalving body condition score and prepartum feeding level on production, reproduction, and health parameters in pasture-based transition dairy cows. J. Dairy Sci. 98:7164-7182. https://doi.org/10.3168/jds.2014-9269.

Seo, J., J. S. Osorio, and J. J. Loor. 2013. Purinergic signaling gene network expression in bovine polymorphonuclear neutrophils during the peripartal period. J. Dairy Sci. 96:7675-7683. https://doi. org/10.3168/jds.2013-6952.

Spurgeon, S. L., R. C. Jones, and R. Ramakrishnan. 2008. High throughput gene expression measurement with real time PCR in a microfluidic dynamic array. PLoS One 3:e1662. https://doi. org/10.1371/journal.pone.0001662.

Vandesompele, J., K. De Preter, F. Pattyn, B. Poppe, N. Van Roy, A. De Paepe, and F. Speleman. 2002. Accurate normalization of real-time quantitative RT-PCR data by geometric averaging of multiple internal control genes. Genome Biol. 3:RESEARCH0034.

Viturro, E., C. Altenhofer, B. Zölch, A. Burgmaier, I. Riedmaier, and M. W. Pfaffl. 2014. Microfluidic high-throughput reversetranscription quantitative PCR analysis of liver gene expression in lactating animals. Microchim. Acta. 13:1725-1732. https://doi. org/10.1007/s00604-014-1205-x.

Vorachek, W. R., Hugejiletu, G. Bobe, and J. A. Hall. 2013. Reference gene selection for quantitative PCR studies in sheep neutrophils. Int. J. Mol. Sci. 14:11484-11495. https://doi.org/10.3390/ ijms140611484.

Walker, C. G., S. Meier, M. D. Mitchell, J. R. Roche, and M. Littlejohn. 2009. Evaluation of real-time PCR endogenous control genes for analysis of gene expression in bovine endometrium. BMC Mol. Biol. 10:100. https://doi.org/10.1186/1471-2199-10-100.

White, A. K., M. VanInsberghe, O. I. Petriv, M. Hamidi, D. Sikorski, M. A. Marra, J. Piret, S. Aparicio, and C. L. Hansen. 2011. High-throughput microfluidic single-cell RT-qPCR. Proc. Natl. Acad. Sci. USA 108:13999-14004. https://doi.org/10.1073/ pnas.1019446108.

Wright, H. L., H. B. Thomas, R. J. Moots, and S. W. Edwards. 2013. RNA-seq reveals activation of both common and cytokine-specific pathways following neutrophil priming. PLoS One 8:e58598. https://doi.org/10.1371/journal.pone.0058598.

Yuan, J. S., A. Reed, F. Chen, and C. N. Stewart. 2006. Statistical analysis of real-time PCR data. BMC Bioinformatics 7:85. https://doi.org/10.1186/1471-2105-7-85.

Zhang, X., L. Ding, and A. J. Sandford. 2005. Selection of reference genes for gene expression studies in human neutrophils by real-time PCR. BMC Mol. Biol. 6:4. https://doi.org/10.1186/1471-2199-6-4. 